\title{
Granulosa cells of the cumulus oophorus are different from mural granulosa cells in their response to gonadotrophins and IGF-I
}

\author{
F Khamsi $^{1,2}$ and $\mathbf{S}$ Roberge ${ }^{1}$ \\ ${ }^{1}$ Toronto Fertility Sterility Institute, Toronto, Ontario, Canada \\ ${ }^{2}$ Division of Endocrinology and Metabolism, Toronto General Hospital, University Health Network and Department of Medicine, University of Toronto, \\ Toronto, Ontario, Canada \\ (Requests for offprints should be addressed to F Khamsi, Toronto Fertility Sterility Institute, 66 Avenue Road, Toronto, Ontario M5R 3N8, Canada; \\ Email: tfsi@aaa-tfsi.com)
}

\begin{abstract}
There are two types of granulosa cells: those which surround the oocyte are cumulus cells (CC) and those which surround the antrum are mural granulosa cells (MGC). These cells are under the influence of several hormones and growth factors, the most important of which are gonadotrophins and IGF-I. In this article, we report novel observations on the differences between these two types of granulosa cells and their interaction with gonadotrophins and IGF-I. We were able to conduct physiological studies on the role of IGF-I by using an analogue of IGF-I which does not bind to IGF-I-binding proteins $\left(\mathrm{LR}^{3}\right.$-IGF-I). Immature rats received saline, equine chorionic gonadotrophin (eCG), $\mathrm{LR}^{3}$-IGF-I or eCG plus $\mathrm{LR}^{3}$-IGF-I by infusion using a pump from 24-29 days of age. The rats were killed and the ovaries removed. Surface follicles were punctured and MGC and oocyte cumulus complexes were removed. These were cultured in saline (control) and in three different doses of FSH. Cell repli-
\end{abstract}

cation was assessed by ${ }^{3} \mathrm{H}$-thymidine incorporation and differentiation was evaluated by the measurement of progesterone secretion. It was noted that $\mathrm{CC}$ replicated ten times more than MGC. Similarly, progesterone secretion by $\mathrm{CC}$ was six times more than by MGC. In vivo exposure to gonadotrophins (eCG) positively influenced in vitro treatment with FSH in both cell types. This phenomenon was observed in both cell replication and progesterone secretion. The IGF-I analogue had a positive effect on cell replication of MGC but a negative effect on the cell replication of $\mathrm{CC}$. With respect to progesterone secretion, the IGF-I analogue had a negative effect on CC but a positive effect on MGC. In conclusion, CC behaved differently from MGC in response to gonadotrophins and the IGF-I analogue. IGF-I and FSH acted additively, synergistically or antagonistically in different circumstances.

Journal of Endocrinology (2001) 170, 565-573

\section{Introduction}

As the Graafian follicle matures, there are several concentric layers of granulosa cells surrounding the oocyte. When the antrum develops and enlarges, the granulosa cells divide into two functional groups: the cells in immediate contact with the oocyte which are called the cumulus cells (cumulus oophorus, CC) and the mural granulosa cells (MGC) which line the follicular wall around the antrum (Greenwald \& Terranova 1988). There has been evidence showing that CC provide nutrition for the oocyte and influence oocyte development in a paracrine fashion (Brower \& Schultz 1982, Moor 1983). In turn, the oocyte produces materials that influence CC function (Vanderhyden et al. 1990, 1992, Einspanier et al. 1997, Eppig et al. 1997). Until recently, all the investigations reported were with MGC but CC play an important role in oocyte maturation and deserve similar meticulous studies. We have therefore conducted a number of studies using bovine, porcine, murine and human models (Xia et al. 1994, Armstrong et al. 1996, Khamsi \& Armstrong 1997, Khamsi et al. 1999, 2001, Khamsi \& Roberge 2000, 2001) which investigated the physiology and pathology of CC.

Initially, gonadotrophins and insulin-like growth factor-I (IGF-I) were investigated as major factors in follicular development. Although this area has been extensively reviewed (Adashi et al. 1985) we wished to use physiological circumstances in our current murine model to compare CC and MGC and their interactions with gonadotrophins and IGF-I. A problem encountered with parenteral administration of IGF-I is that it becomes bound to its circulating binding proteins and is essentially neutralized. We therefore used an analogue of IGF-I, LR ${ }^{3}$ IGF-I, which binds very little to IGF-I-binding proteins and therefore is free to simulate the role of IGF-I in a physiological fashion (Francis et al. 1992, Ballard et al. 1993). 

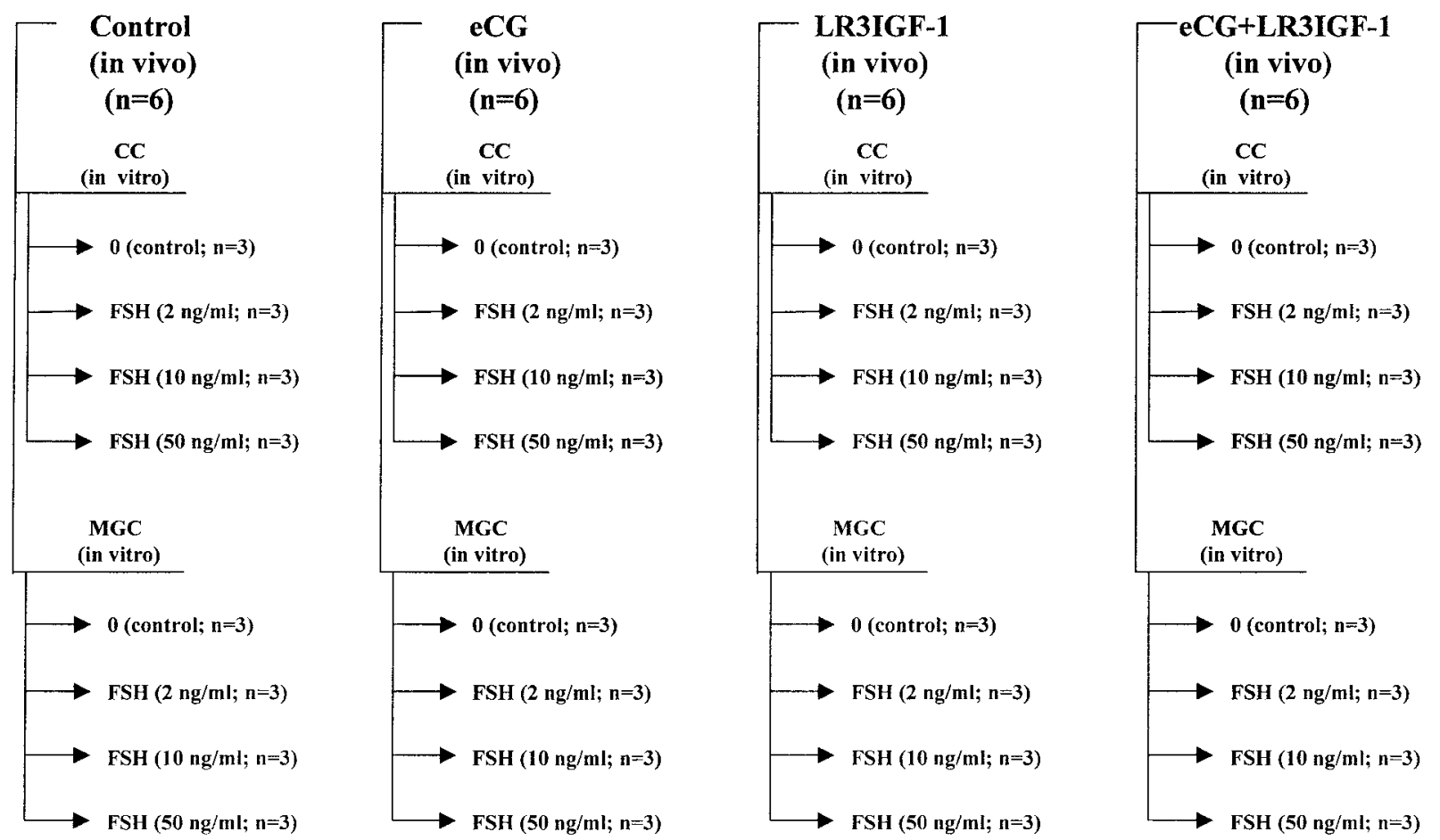

Figure 1 Diagram of the experimental design of this study. Rats (24 days of age) were treated in vivo with eCG, LR ${ }^{3}$-IGF-I, a

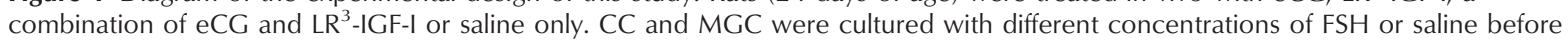
being challenged with ${ }^{3} \mathrm{H}$-thymidine for measurement of replication. This experiment was repeated twice.

\section{Materials and Methods}

\section{Animals and in vivo treatments}

Immature Sprague-Dawley rats were purchased at 20 days of age (Charles River, St Constant, Canada) and were housed in an animal care facility, maintained on a $14 \mathrm{~h}$ light: $10 \mathrm{~h}$ darkness cycle, and provided with food and water available ad libitum in accordance with guidelines on the handling of laboratory animals. A diagram of the experimental design is presented in Fig. 1.

At 24 days of age, rats were stratified by body weight into four groups with equal mean body weights. They were then randomized to receive continuous s.c. infusion of an IGF-I analogue, long $\mathrm{Arg}^{3}$-IGF-I (LR ${ }^{3}$-IGF-I; Gro-Pep Pty Ltd, Adelaide, Australia) at the rate of $1 \mathrm{mg} / \mathrm{kg}$ per day with Alzet mini-osmotic pumps (Alza Corp., Vacavile, CA, USA) or saline. Installation of the pump consisted of one 'jab' of a very fine needle into the subcutaneous tissue. The infusion rate was selected on the basis of previous dose-response studies in rats employing stimulation of growth and anabolic responses as end points of biological efficacy (Francis et al. 1992, Ballard et al. 1993). Infusion of $\mathrm{LR}^{3}$-IGF-I was continued until the rats were killed at 29 days of age.

At 27 days of age, rats were randomized to receive either an s.c. injection of 15 IU equine chorionic gonadotrophin (eCG; Ayerst, Montreal, Canada) or saline only. The injection was given at $0900 \mathrm{~h}$ and the rats were killed (by decapitation) $48 \mathrm{~h}$ later which is the equivalent of pro-oestrus for eCG-treated rats.

Rats were weighed immediately before they were killed and their reproductive tracts removed under aseptic conditions. Ovaries of untreated or eCG-treated rats were dissected from the oviducts and adherent adipose and connective tissues, weighed and placed in HEPESbuffered tissue culture medium 199 (HTCM-199; Sigma, St Louis, MO, USA) for recovery of CC and MGC.

Table 1 Effects of different doses of FSH on ${ }^{3} \mathrm{H}$-thymidine incorporation on cultured CC and MGC of immature rats. The rats were treated in vivo with saline before being killed. Values are means \pm S.E.M. $(n=$ six per group $)$

\section{${ }^{3} \mathrm{H}$-Thymidine incorporation $(\mathrm{dpm})$}

\begin{tabular}{|c|c|c|}
\hline & \\
\hline & $\overline{\mathrm{CC}(\mathrm{dpm} / \mathrm{CC})}$ & MGC $\left(\mathrm{dpm} / 10^{3} \mathrm{MGC}\right)$ \\
\hline \multicolumn{3}{|c|}{$\begin{array}{l}\text { FSH concentration } \\
(\mathrm{ng} / \mathrm{ml})\end{array}$} \\
\hline 0 & $603 \pm 368$ & $43 \pm 4$ \\
\hline 2 & $1548 \pm 326^{*}$ & $50 \pm 5$ \\
\hline 10 & $1855 \pm 341^{*}$ & $72 \pm 6^{*}$ \\
\hline 50 & $1053 \pm 341$ & $77 \pm 4^{*}$ \\
\hline
\end{tabular}

*Values are significantly $(P<0 \cdot 05)$ different from control (no FSH). 

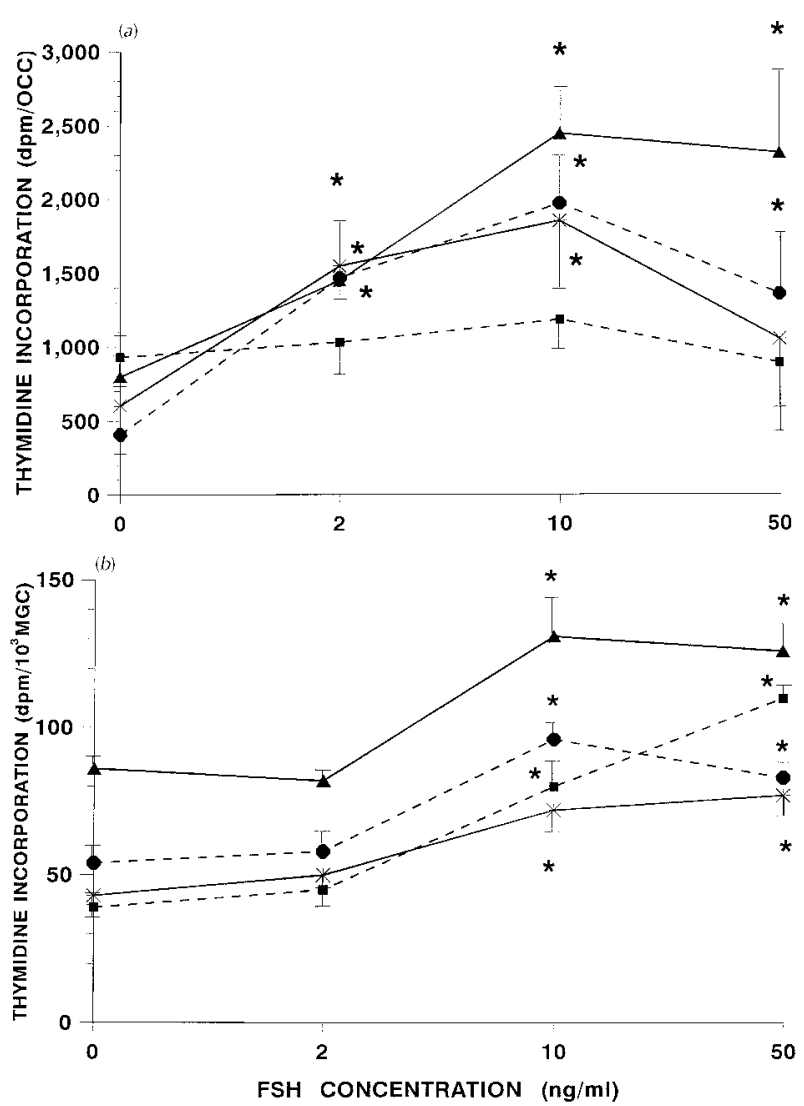

Figure 2 Thymidine incorporation of (a) OCC and (b) MGC from rats treated in vivo with eCG $(\boldsymbol{\Delta}), \mathrm{LR}^{3}$-IGF-I $(\mathbf{\square})$, both $(\mathbf{0})$ or saline $(*)$. Cultured OCC were treated in vitro with different concentrations of FSH. Thymidine incorporation mean values are reported (a) per each OCC and (b) for $10^{3}$ MGC. Data are mean values \pm S.E.M. for pooled data from two experiments, with six in vitro replicates per FSH concentration. Broken lines represent groups that received $L^{3}$-IGF-I (either $L^{3}$-IGF-I or eCG plus $\left.\mathrm{LR}^{3}-\mathrm{IGF}-\mathrm{I}\right)$. Asterisks indicate values significantly different from control (no IGF-I), within the same in vivo treatment $(P<0 \cdot 05)$.

\section{Cell culture and in vitro treatments}

Surface follicles (approximately 30 follicles per rat) on the ovaries were punctured with a hypodermic needle and subsequently the ovaries were gently compressed with forceps and agitated in the culture medium to release oocyte cumulus complexes (OCC) and MGC. CC were the cells surrounding the oocyte which were adhered together and to the oocyte. MGC were the loose cells in the follicular fluid. CC had a 'shiny' appearance which was distinct from MGC. Pooled OCC from several rats in each in vivo treatment were rinsed through two successive washes in HTCM-199 and a final rinse in bicarbonatebuffered medium (BTCM-199). Ten to fifteen OCC were then transferred at random to each well of a 96-well tissue culture plate (Nalge Nunc International,
Table 2 Effects of different doses of FSH on ${ }^{3} \mathrm{H}$-thymidine incorporation on cultured CC and MGC of immature rats. The rats were treated in vivo with eCG before being killed. Values are means \pm S.E.M. ( $n=$ six per group)

${ }^{3} \mathrm{H}$-Thymidine incorporation $(\mathrm{dpm})$

\begin{tabular}{|c|c|c|}
\hline \multirow{3}{*}{$\begin{array}{l}\text { FSH concentration } \\
(\mathrm{ng} / \mathrm{ml})\end{array}$} & \\
\hline & $\overline{C C}(\mathrm{dpm} / \mathrm{CC})$ & MGC (dpm/10 $0^{3}$ MGC) \\
\hline & & \\
\hline 0 & $797 \pm 301$ & $86 \pm 4$ \\
\hline 2 & $1448 \pm 48^{*}$ & $82 \pm 2$ \\
\hline 10 & $2447 \pm 399^{*}$ & $131 \pm 9^{*}$ \\
\hline 50 & $2315 \pm 628^{*}$ & $126 \pm 4^{*}$ \\
\hline
\end{tabular}

Napierville, IL, USA) containing BTCM-199. OCC consisted of one oocyte and approximately 30 granulosa cells.

Pooled MGC from all rats of the same in vivo treatment were suspended and washed twice in HTCM-199 and resuspended in BTCM-199 after the second wash, with centrifugation at $400 \mathrm{~g}$ for $10 \mathrm{~min}$ after each wash. The number of MGC was counted with a haemocytometer, and their viability was assessed by trypan blue dye exclusion (Sigma). The final MGC suspension was delivered into wells of a 96-well tissue culture plate and the volume was adjusted to $0.25 \mathrm{ml}$ to give final MGC concentrations of $4 \times 10^{5}$ viable cells $/ \mathrm{ml}$. Each culture well received ovine follicle-stimulating hormone (FSH; NIADDKoFSH-17) at one of the following concentrations: 2, 10, $50 \mathrm{ng} / \mathrm{ml}$ or no hormone (control). After the addition of the in vitro treatments, $\mathrm{CC}$ and $\mathrm{MGC}$ were incubated for $20 \mathrm{~h}$ in a humidified atmosphere of $5 \% \mathrm{CO}_{2}$ in air at $37.5{ }^{\circ} \mathrm{C}$ in a water-jacketed tissue culture incubator (Forma Scientific, Marietta, OH, USA). At the end of the incubation period, $1 \mu \mathrm{Ci}{ }^{3} \mathrm{H}$-thymidine (ICN Biochemicals, Irvine, CA, USA; $20 \mathrm{Ci} / \mathrm{mmol}$ ) was added to each well and cultures were continued for a further $8 \mathrm{~h}$. Cells were then harvested with a Skatron cell harvester (Fisher Scientific Ltd, Nepean, ON, Canada). Radioactivity not incorporated into DNA was washed off the OCC and MGC by two rinses with BTCM-199. The filter disks containing the cells were air-dried, and incorporated radioactivity was counted with a liquid scintillation spectrometer for the measurement of ${ }^{3} \mathrm{H}$-thymidine incorporation. This was interpreted as an index of DNA synthesis.

In vitro dose-response with FSH was performed using six rats per in vivo treatment, and three in vitro replicates per FSH concentration. Progesterone secretion was utilized as an index of steroidogenic differentiation. Progesterone was measured by a specific radioimmunoassay of unextracted aliquots of culture medium removed immediately before the cells were harvested (Leung \& Armstrong 1979). 
Table 3 Effects of different doses of FSH on ${ }^{3} \mathrm{H}$-thymidine incorporation on cultured CC and MGC of immature rats. The rats were treated in vivo with LR ${ }^{3}$-IGF-I before being killed. Values are means \pm S.E.M. $(n=$ six per group $)$

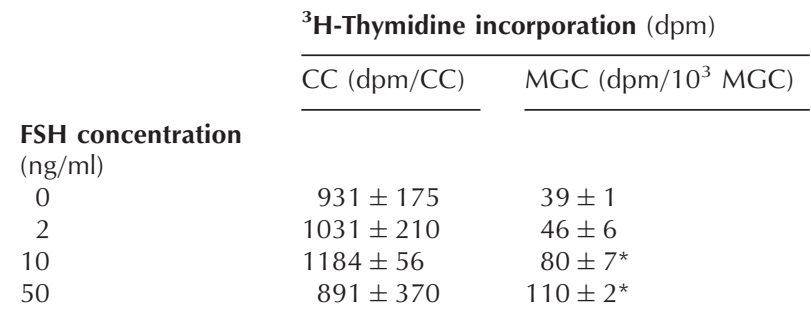

*Values are significantly $(P<0 \cdot 05)$ different from control (no FSH).

Table 4 Effects of different doses of FSH on ${ }^{3} \mathrm{H}$-thymidine incorporation on cultured $\mathrm{CC}$ and MGC of immature rats. The rats were treated in vivo with eCG $+\mathrm{LR}^{3}$-IGF-I before being killed. Values are means \pm S.E.M. $(n=$ six per group)

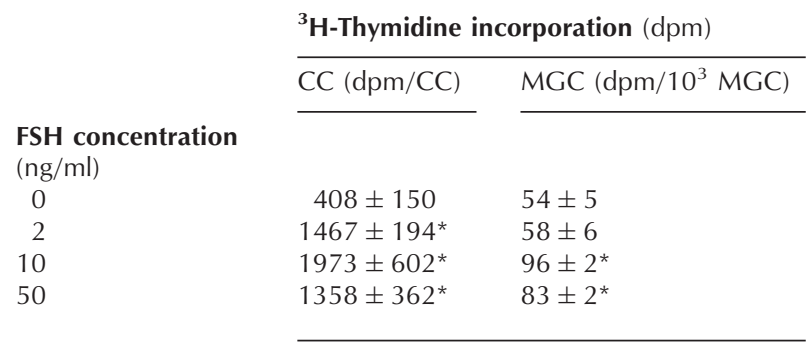

*Values are significantly $(P<0 \cdot 05)$ different from control (no FSH).

\section{Statistical analysis}

Six rats were utilized for each in vivo treatment. The OCC were pooled from the six rats and divided into four groups for each of the four in vitro treatments (saline and three different doses of FSH). Each of the aliquots containing a specific dose of FSH was divided into three equal parts and the reading of ${ }^{3} \mathrm{H}$-thymidine incorporation was obtained in three different samples. The whole experiment was repeated once more which yielded six readings for each dose group. The data were subjected to analysis of variance (ANOVA) which produced $F$ statistics to compare variation attributed to specific treatment, e.g. $\mathrm{LR}^{3}$-IGF-I, eCG etc. with the calculation of random error. We show comparisons in the figures and tables.

\section{Results \\ Cell replication}

Dose-response curve to FSH comparing MGC with CC Table 1 and Fig. 2 show that the baseline ${ }^{3} \mathrm{H}$-thymidine incorporation was more than ten times higher in CC than in MGC per cell. Both cell types showed a response to FSH but the dose-response curves were different. With CC, it peaked at $10 \mathrm{ng} / \mathrm{ml} \mathrm{FSH}$ whereas with MGC it continued to rise up to the highest dose of FSH tested $(50 \mathrm{ng} / \mathrm{ml})$.

Dose-response curve to FSH with prior treatment with eCG Table 2 and Fig. 2 demonstrate that prior exposure to eCG increased the rate of ${ }^{3} \mathrm{H}$-thymidine incorporation at all dose levels of FSH in MGC and most dose levels of FSH in CC. The response curve was different between CC and MGC. With both cell types the dose-response curves flattened after the dose of $10 \mathrm{ng} / \mathrm{ml}$ FSH.

Dose-response curve to FSH with prior treatment with $\mathbf{L R}^{3}$-IGF-I Table 3 and Fig. 2 demonstrate that prior exposure to IGF-I analogue resulted in quite different responses to FSH in vitro of CC compared with MGC. There was an apparent increase in the MGC, whereas in the $\mathrm{CC}$ there was a reduction in ${ }^{3} \mathrm{H}$-thymidine incorporation. In the MGC there was a stimulatory effect of the IGF-I analogue which appeared to act synergistically with in vitro $\mathrm{FSH}$. In the $\mathrm{CC}$ there was a reduction in cell replication at all dose levels of FSH, i.e. IGF-I analogue in vivo appeared to act antagonistically with in vitro $\mathrm{FSH}$ exposure.

Dose-response curve to FSH with prior exposure to $\mathbf{L R}^{3}$-IGF-I and eCG Table 4 and Fig. 2, when compared with Table 1, show a more modest effect of combined LR $^{3}$-IGF-I and eCG compared with eCG alone on MGC replication. This combination also appeared to have a more modest effect than eCG on CC. Looking at the curves, $\mathrm{LR}^{3}$-IGF-I plus eCG appeared to reduce the stimulating effect of $\mathrm{eCG}$ on $\mathrm{CC}$ or $\mathrm{MGC}$ proliferation. In vivo exposure to the IGF-I analogue appeared to act antagonistically with respect to gonadotrophin (eCG) also administered in vivo. The curves of eCG alone or eCG plus IGF-I analogue are fairly similar but it is of note that after a dose of $10 \mathrm{ng} / \mathrm{ml} \mathrm{FSH} \mathrm{the}$ response declined. It appears that higher doses of FSH in vitro have a further antagonistic interaction with IGF-I analogue given in vivo.

\section{Progesterone secretion}

Progesterone secretion by CC The results are shown in Fig. 3b. The raw means for CC, displayed for all treatment groups and dosages of FSH, indicated some strong patterns of difference among the three factors (Table 5). ANOVA (Table 6) indicated significant differences among many of the contrasts tested. In particular, the interactions between the dose of FSH compared with eCG or IGF-I were significant at the $P<0 \cdot 001$ level. In the presence of an interaction between all three factors, eCG, LR $^{3}$-IGF-I and dose of FSH, one cannot make 

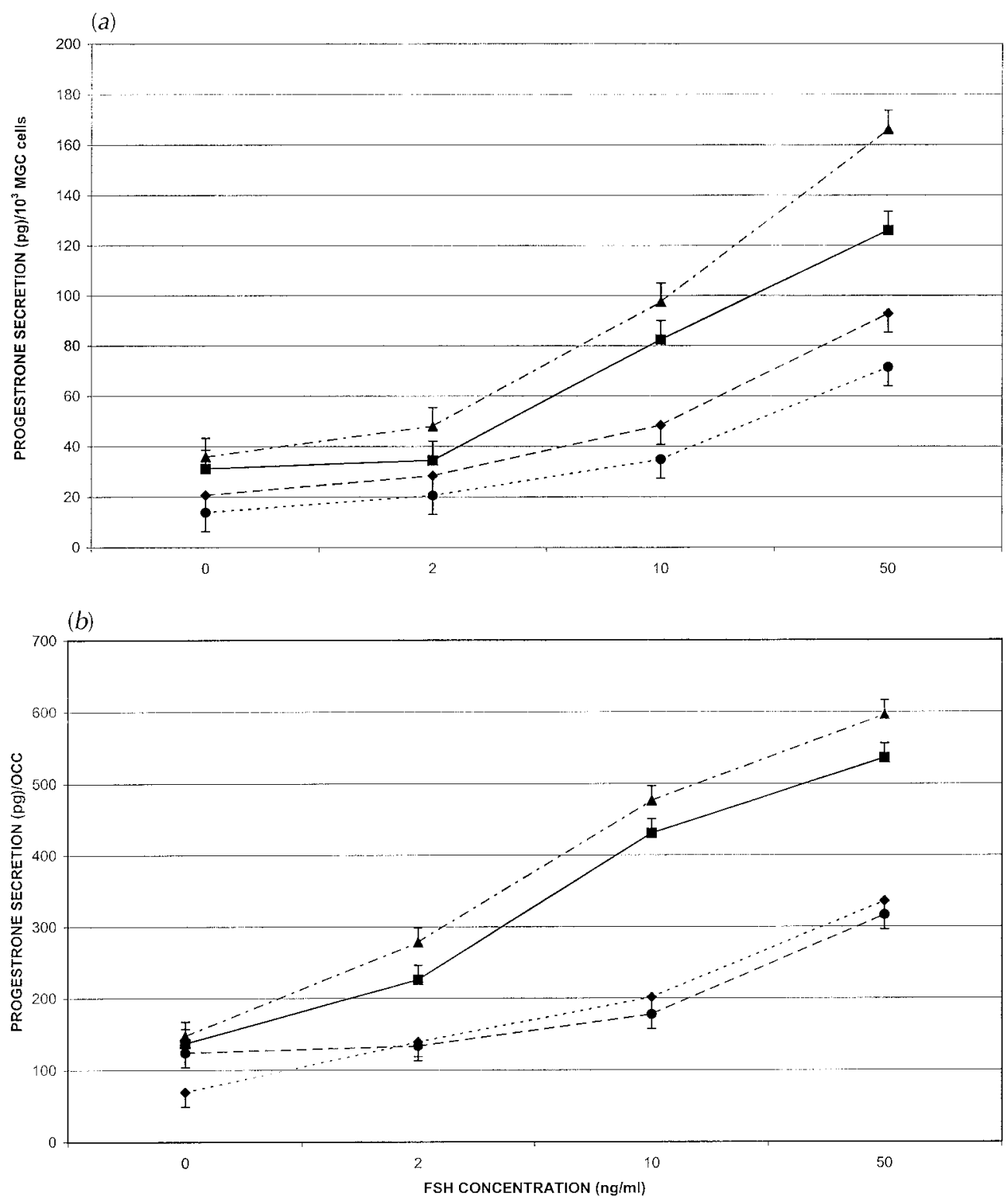

Figure 3 Progesterone secretion of (a) MGC and (b) OCC from rats treated in vivo with eCG LR $^{3}$-IGF-I $(\bullet)$, both $(\boldsymbol{\Delta})$ or saline $(\boldsymbol{\bullet})$. Cultured CC were treated in vitro with different concentrations of FSH. Progesterone secretion mean values are reported (a) for $10^{3} \mathrm{MGC}$ or (b) per each OCC. Data are mean values \pm S.E.M. for pooled data from two experiments, with six in vitro replicates per FSH concentration.

simple statements about the main effect of any factor. However, the following deductions can be made.

1. Levels of progesterone increased with dose of FSH; the rate of increase was linear with log dose of FSH.

2. Rates of increase were consistently higher when eCG was present than when it was absent (Table 7).

3. The effect of $\mathrm{LR}^{3}$-IGF-I on the slope when eCG was absent was negative; the slope was lower when $\mathrm{LR}^{3}$-IGF-I was present than when it was absent. The effect of $\mathrm{LR}^{3}$-IGF-I on the slope when eCG was present was positive; the slope was higher when $\mathrm{LR}^{3}$-IGF-I was present than when it was absent.

Progesterone secretion by MGC The results are shown in Fig. 3a. The table of means for MGC cells also indicated strong patterns for eCG, $\mathrm{LR}^{3}$-IGF-I and dose 
Table 5 Table of means for CC

\begin{tabular}{|c|c|c|c|c|c|c|}
\hline & \multicolumn{4}{|c|}{ Dose of FSH (ng/ml) } & \multirow{2}{*}{$\begin{array}{l}\text { Mean square } \\
\text { error }\end{array}$} & \multirow[b]{2}{*}{ Total error } \\
\hline & 0 & 2 & 10 & 50 & & \\
\hline \multicolumn{7}{|l|}{ Group } \\
\hline eCG & $137 \cdot 00$ & $226 \cdot 00$ & $430 \cdot 83$ & $536 \cdot 33$ & $332 \cdot 54$ & $S^{2}=408 \cdot 1$ \\
\hline IGF-I & $123 \cdot 83$ & $133 \cdot 17$ & $177 \cdot 17$ & $316 \cdot 67$ & $187 \cdot 71$ & $S=20 \cdot 2$ \\
\hline Combination & $147 \cdot 17$ & $278 \cdot 00$ & $476 \cdot 50$ & $596 \cdot 33$ & $374 \cdot 50$ & \\
\hline Control & $69 \cdot 17$ & $138 \cdot 83$ & $201 \cdot 17$ & $336 \cdot 00$ & $186 \cdot 29$ & \\
\hline Total & $119 \cdot 29$ & $194 \cdot 00$ & $321 \cdot 42$ & $446 \cdot 33$ & $270 \cdot 26$ & \\
\hline
\end{tabular}

$S$, square root of mean; $S^{2}$, mean square of the error.

of FSH (Table 8). In this instance, however, ANOVA (Table 9) indicated no statistically significant interactions except with dose of FSH. The term dose, eCG and IGF-I were not significant, indicating that changes in progesterone secretion for different levels of dose were less complex for MGC than for CC. Also the term eCG or IGF-I were not significant $(P=0 \cdot 057)$, suggesting that these factors do not modify each other's effects. The following general statements can therefore be made.

1. Increasing doses of FSH increased the level of progesterone secretion in each of the four combinations of treatments (Table 9). There was a strong linear component to this change. There was also evidence of significant departure from linearity for all but the eCG group.

2. The presence of eCG was associated with a consistently higher slope.
3. The presence of $\mathrm{LR}^{3}$-IGF-I was also associated with a consistently higher slope. The effect of $\mathrm{LR}^{3}$-IGF-I was, however, less dramatic than the effect of eCG. The magnitude of these effects could be estimated from the table of means since no interactions have been demonstrated (Table 10).

\section{Discussion}

Innate replication and progesterone secretion of OCC compared with MGC

The first obvious finding was that cell replication, as judged by ${ }^{3} \mathrm{H}$-thymidine incorporation, was tenfold higher in CC compared with MGC (comparing Fig. $2 a$ with $b$ ). This phenomenon was in agreement with results of radioautographic studies in rats, in which ${ }^{3} \mathrm{H}$-thymidine

Table 6 ANOVA table for CC. Number of observations=96; R-squared=0.9900; root MSE=20.2023; adjusted R-squared $=0.9842$

\begin{tabular}{|c|c|c|c|c|c|}
\hline & Partial SS & df & MS & $F$ & $P$ \\
\hline \multicolumn{6}{|l|}{ Source } \\
\hline \multicolumn{6}{|l|}{ Main } \\
\hline ID & $18669 \cdot 9271$ & 5 & $3733 \cdot 98542$ & $2 \cdot 86$ & $0 \cdot 0524$ \\
\hline eCG & $665500 \cdot 51$ & 1 & $665500 \cdot 51$ & $1630 \cdot 59$ & $<0.001$ \\
\hline IGF & $11288 \cdot 3438$ & 1 & $11288 \cdot 3438$ & $27 \cdot 66$ & $<0 \cdot 001$ \\
\hline $\mathrm{eCG}^{\star} \mathrm{IGF}$ & $9861 \cdot 76042$ & 1 & $9861 \cdot 76042$ & $24 \cdot 16$ & $<0 \cdot 001$ \\
\hline Error (A) & $19602 \cdot 1979$ & 15 & $1306 \cdot 81319$ & & \\
\hline \multicolumn{6}{|l|}{ Subplots } \\
\hline Dose & $1493420 \cdot 36$ & 3 & $497806 \cdot 788$ & $1219 \cdot 71$ & $<0 \cdot 001$ \\
\hline Dose $^{*}$ eCG & 193 064.031 & 3 & $64354 \cdot 6771$ & $157 \cdot 68$ & $<0 \cdot 001$ \\
\hline Dose*IGF & $1421 \cdot 69792$ & 3 & $473 \cdot 899306$ & $1 \cdot 16$ & 0.3321 \\
\hline Dose*IGF*eCG & $14817 \cdot 6146$ & 3 & $4939 \cdot 20486$ & $12 \cdot 10$ & $<0 \cdot 001$ \\
\hline Error $(\mathrm{B})$ & $24488 \cdot 0417$ & 60 & $408 \cdot 134028$ & & \\
\hline Total & $2452134 \cdot 49$ & 95 & $25811 \cdot 942$ & & \\
\hline
\end{tabular}

MSE, mean square of error; ID, control; eCG, equine chorionic gonadotrophin; SS, sum of squares; MS, mean sum of squares. The errors represent the SS for the error in each of the ANOVAs. 
Table 7 Table of slopes for CC. Rate of change per fivefold increase in dose of FSH

\begin{tabular}{|c|c|c|}
\hline \multirow[b]{3}{*}{ LR ${ }^{3}$-IGF-I } & \multicolumn{2}{|l|}{ eCG } \\
\hline & Absent & Presen \\
\hline & & \\
\hline Absent & $98 \cdot 6$ & $155 \cdot 2$ \\
\hline Present & $91 \cdot 8$ & $159 \cdot 2$ \\
\hline
\end{tabular}

incorporation in antral follicles was much higher in CC than in MGC (Takaoka et al. 1985, Hirshfield 1986).

The same difference between CC and MGC was seen in progesterone secretion when CC (per cell) secreted about sixfold higher levels of progesterone than MGC. Were these differences exclusively related to the different cells or were the CC influenced by the oocyte? We are

Table 8 Table of means for MGC

\begin{tabular}{|c|c|c|c|c|c|c|}
\hline & Dose & $(\mathrm{ng} / \mathrm{ml}$ & & & & \\
\hline & 0 & 2 & 10 & 50 & error & Total error \\
\hline Group & & & & & & \\
\hline eCG & $31 \cdot 17$ & $34 \cdot 50$ & $82 \cdot 50$ & $126 \cdot 00$ & $68 \cdot 54$ & $\begin{array}{l}S^{2}=56 \cdot 30 \\
S=7 \cdot 50\end{array}$ \\
\hline IGF-I & $20 \cdot 67$ & $28 \cdot 33$ & $48 \cdot 33$ & $92 \cdot 83$ & $47 \cdot 54$ & $S=7 \cdot 50$ \\
\hline Combination & $35 \cdot 83$ & $48 \cdot 00$ & $97 \cdot 50$ & $166 \cdot 17$ & $86 \cdot 88$ & \\
\hline Control & $13 \cdot 38$ & $20 \cdot 50$ & $34 \cdot 83$ & $71 \cdot 50$ & $35 \cdot 17$ & \\
\hline Total & $25 \cdot 38$ & $32 \cdot 83$ & $65 \cdot 79$ & $114 \cdot 12$ & $59 \cdot 53$ & \\
\hline
\end{tabular}

Table 9 ANOVA table for MGC. Number of observations=96; R-squared=0.9805; root MSE=7.50375; R-squared $=0.9692$

\begin{tabular}{|c|c|c|c|c|c|}
\hline & Partial SS & df & MS & $F$ & $P$ \\
\hline \multicolumn{6}{|l|}{ Source } \\
\hline \multicolumn{6}{|l|}{ Main } \\
\hline ID & $792 \cdot 59375$ & 5 & $158 \cdot 51875$ & $1 \cdot 44$ & $0 \cdot 2668$ \\
\hline eCG & $31719 \cdot 0104$ & 1 & $31719 \cdot 0104$ & $563 \cdot 33$ & $0 \cdot 001$ \\
\hline IGF & $5658 \cdot 01042$ & 1 & $5658 \cdot 01042$ & $100 \cdot 49$ & $0 \cdot 001$ \\
\hline $\mathrm{eCG}^{*} \mathrm{IGF}$ & $213 \cdot 010417$ & 1 & $213 \cdot 010417$ & $3 \cdot 78$ & $0 \cdot 0565$ \\
\hline Error (A) & $1651 \cdot 53125$ & 15 & $110 \cdot 102083$ & & \\
\hline \multicolumn{6}{|l|}{ Subplots } \\
\hline Dose & $117578 \cdot 365$ & 3 & $39192 \cdot 7882$ & 696.06 & $0 \cdot 001$ \\
\hline Dose $^{*} \mathrm{eCG}$ & $10142 \cdot 6146$ & 3 & $3380 \cdot 87153$ & $60 \cdot 04$ & $0 \cdot 001$ \\
\hline Dose*IGF & $2114 \cdot 78125$ & 3 & $704 \cdot 927083$ & $12 \cdot 52$ & $0 \cdot 001$ \\
\hline Dose ${ }^{\star}$ GF* $^{*}$ CG & $377 \cdot 614583$ & 3 & $125 \cdot 871528$ & $2 \cdot 24$ & 0.0933 \\
\hline Error (B) & $3378 \cdot 375$ & 60 & $56 \cdot 30625$ & & \\
\hline Total & $173625 \cdot 906$ & 95 & $1827 \cdot 64112$ & & \\
\hline
\end{tabular}

For definitions of terms see Table 6 .

Table 10 Table of slopes for MGC. Rate of change per fivefold increase in dose of FSH

\begin{tabular}{|c|c|c|}
\hline & \multicolumn{2}{|l|}{ eCG } \\
\hline & Absent & Present \\
\hline LR ${ }^{3}$-IGF-I & & \\
\hline Absent & $25 \cdot 5$ & $45 \cdot 8$ \\
\hline Present & $32 \cdot 3$ & $59 \cdot 1$ \\
\hline
\end{tabular}

undertaking further studies removing the oocytes from OCC to investigate the possibilities.

The difference between OCC compared with MGC in their response to in vivo $L R^{3}-I G F-I$ treatment

There was a difference as judged by ${ }^{3} \mathrm{H}$-thymidine incorporation or progesterone secretion. $\mathrm{LR}^{3}$-IGF-I given in vivo increased ${ }^{3} \mathrm{H}$-thymidine incorporation and progesterone secretion in MGC whereas it had a reverse effect 
with OCC. One possible explanation may be that $\mathrm{LR}^{3}-$ IGF-I loosens the connection of CC from the oocyte and therefore results in this reverse effect.

\section{Shape of the response curves}

It can be seen that CC and MGC had different response curves to FSH. For example, the effect of FSH peaked at the $10 \mathrm{ng} / \mathrm{ml}$ dose for CC whereas it continued to climb up to the $50 \mathrm{ng} / \mathrm{ml}$ dose for MGC, as judged by ${ }^{3} \mathrm{H}$-thymidine incorporation.

\section{Interaction of $L R^{3}-I G F-I$ and $e C G$}

Progesterone secretion data showed that these two factors had an additive effect in MGC compared with a synergistic effect in CC. When the ${ }^{3} \mathrm{H}$-thymidine incorporation data were reviewed (Fig. 2) it could be seen that for both CC and MGC, LR $^{3}$-IGF-I had a negative effect on eCG stimulation. What can be the explanation for the difference in cell replication compared with progesterone secretion (an indicator of maturation) in the interaction of $\mathrm{LR}^{3}$-IGF-I and eCG? It is conceivable that IGF-I encourages cell maturation in eCG-treated animals and that it therefore causes reduced cell replication but increased progesterone secretion.

In conclusion, a rather complex picture of the relationship between gonadotrophins (eCG) and IGF-I $\left(\mathrm{LR}^{3}-\mathrm{IGF}-\mathrm{I}\right)$ is emerging. These two chemicals may act synergistically (progesterone secretion by CC), additively (progesterone secretion by MGC) or antagonistically (cell replication of CC and MGC).

\section{Acknowledgements}

We express our sincere thanks to Dr D T Armstrong from the Department of Obstetrics and Gynaecology of the University of Western Ontario, London, Ontario, Canada for support and guidance, and to Ms Anne Rouleau and Mr Gerry Barbe for their technical assistance. We are grateful to Professor Mary Chipman and Joel R K Moody from the Research Services Unit, Department of Public Health Sciences at the University of Toronto for their expert opinion and statistical analysis of the data. We wish to acknowledge Serono Laboratories Canada Inc. for their financial support. We would also like to thank Patricia Areias for typing the manuscript. This work was presented at the 46th Annual Meeting of the Canadian Fertility and Andrology Society, St John's, Newfoundland, Canada, 13-16 September 2000.

\section{References}

Adashi EY, Resnick CE, D’Ercole AJ, Svoboda ME \& Van Wyk JJ 1985 Insulin-like growth factors as intraovarian regulators of granulosa cell growth and function. Endocrine Reviews $\mathbf{6}$ 400-420.

Armstrong DT, Xia P, de Gannes G, Tekpetey FR \& Khamsi F 1996 Differential effects of insulin-like growth factor-I and folliclestimulating hormone on proliferation and differentiation of bovine cumulus cells and granulosa cells. Biology of Reproduction $\mathbf{5 4}$ 331-338.

Ballard FJ, Francis GL, Walton PE, Knowles SE, Owens PC, Read LC \& Tomas FM 1993 Modification of animal growth with growth hormone and insulin-like growth factors. Australian Journal of Agricultural Sciences 44 567-577.

Brower PT \& Schultz RM 1982 Intercellular communication between granulosa cells and mouse oocytes: existence and possible role during oocyte growth. Developmental Biology 90 144-153.

Einspanier R, Lauer B, Gabler C, Kamhuber M \& Schams D 1997 Egg-cumulus-oviduct interactions and fertilization. Advances in Experimental Medicine and Biology 44 279-289.

Eppig JJ, Chesnel F, Hirao Y, O’Brein MJ, Pendola FL, Watanabe S \& Wigglesworth K 1997 Oocyte control of granulosa cell development: how and why. Human Reproduction $\mathbf{1 2}$ 127-132.

Francis GL, Ross M, Ballard FJ, Milner SJ, Senn C, McNeil KM, Wallace JC, King R \& Wells JRE 1992 Novel recombinant fusion protein analogues of insulin-like growth factor (IGF)-I indicate the relative importance of IGF-binding protein and receptor binding for enhanced biological potency. Journal of Molecular Endocrinology 8 213-223.

Greenwald GS \& Terranova PF 1988 Follicular selection and its control. In The Physiology of Reproduction, vol 1, pp 387-445. Eds E Knobil \& J Neill. New York: Raven Press.

Hirshfield AN 1986 Patterns of ${ }^{3} \mathrm{H}$ thymidine incorporation differ in immature rats and mature cycling rats. Biology of Reproduction 34 229-235.

Khamsi F \& Armstrong DT 1997 Interactions between follicle-stimulating hormone and growth factors in regulation of deoxyribonucleic acid synthesis in bovine granulosa cells. Biology of Reproduction 57 684-688.

Khamsi F \& Roberge S 2000 Novel studies on influence of gonadotrophins and insulin-like growth factor-I on growth of cumulus oophorus in the rat. Endocrine 12 41-45.

Khamsi F \& Roberge S 2001 Differential effects of insulin-like growth factor-I (IGF-I) and gonadotrophins on the proliferative activity of two subgroups of granulosa cells: cumulus oophorus and mural granulosa cells. Fertility and Sterility 75 997-1002.

Khamsi F, Roberge S, Lacanna I C, Wong J \& Yavas Y 1999 Effects of granulosa cells, cumulus cells, and oocyte density on in vitro fertilization in women. Endocrine 10 161-166.

Khamsi F, Roberge S \& Wong J 2001 Novel demonstration of a physiological/pharmacological role of insulin like growth factor-1 (IGF1) in ovulation in rats and action on cumulus oophorus. Endocrine 14 175-180.

Leung PCK \& Armstrong DT 1979 Estrogen treatment of immature rats inhibits ovarian androgen production in vitro. Endocrinology 104 1411-1417.

Moor RM 1983 Contact, signalling and cooperation between follicle cells and dictyate oocytes in mammals. In Current Problems in Germ Cell Differentiation, pp 307-324. Eds A McLaren \& CC Wylie. Cambridge: University Press.

Takaoka H, Satoh H, Makinoda S, Moriya S \& Ichinoe K 1985 Granulosa cells growth factor in oocyte and its transport system. Acta Obstetrica et Gynaecologica Japonica 37 92-98.

Vanderhyden BC, Caron PJ, Buccione R \& Eppig JJ 1990 Developmental pattern of the secretion of cumulus-expansion enabling factor by mouse oocytes and the role of oocytes in promoting granulosa cell differentiation. Developmental Biology 140 $307-317$. 
Vanderhyden BC, Telfer EE \& Eppig JJ 1992 Mouse oocytes promote proliferation of granulosa cells from preantral and antral follicles in vitro. Biology of Reproduction 46 1196-1204.

Xia P, Tekpetey FR \& Armstrong DT 1994 Effect of IGF-I on pig oocyte maturation, fertilization rate and early embryonic development in vitro, and on granulosa and cumulus cell biosynthetic activity. Molecular Reproduction and Development 38 373-379.

Received 9 May 2001

Accepted 16 May 2001 